\title{
EPISTEMOLOGI KEILMUAN INTEGRATIF- INTERKONEKTIF M. AMIN ABDULLAH DAN IMPLEMENTASINYA DALAM KEILMUAN ISLAM
}

\section{Atika Yulanda}

UIN Sunan Kalijaga Yogyakarta

Email:yulandaatika@gmail.com

\begin{abstract}
The development of human life also develops existing knowledge. Between one science with other scientific interrelated and related to one another. But today, there has been a dichotomy between the scientific sciences and the scientific sciences. Each science separates from one another and is not related to each other. This is also influenced by Islamic culture itself which considers that scholarship originating from the West can lead to disbelief. Therefore, efforts are needed to unite the two scholarships to avoid a dichotomy between the two. This effort was carried out by several figures. One figure who seeks to combine the two sciences is Amin Abdullah. He is an Indonesian Islamic intellectual. The unification of the two sciences above is done by sparking an interconnective integrative idea that is applied directly at UIN Sunan Kalijaga. This integrative-interconnection seeks to combine religious scholarship with science and philosophy. The effort made by a Muslim thinker and intellectual in the form of physical buildings and scientific matters at UIN Sunan Kalijaga. For example the integration between the Islamic Scientific Building with science that was never done before. Whereas in terms of science that is including general subjects in Islamic studies and vice versa so that there is no separation or dichotomy between the two sciences.

Semakin berkembangnya kehidupan manusia maka berkembang pula keilmuan yang ada. Antara satu ilmu dengan keilmuan lainnya saling berkaitan dan berhubungan satu sama lain. Namun dewasa ini, telah terjadi dikotomi keilmuan antara ilmu-ilmu agama dengan keilmuan sains. Masing-masing keilmuan saling memisahkan diri dan tidak saling terkait. Ini juga dipengaruhi oleh kebudayaan Islam itu sendiri yang menganggap bahwa keilmuan yang berasal dari Barat bisa membawa kepada kekafiran.
\end{abstract}

$$
\text { TAJDID Vol. 18, No. 1, Januari - Juni } 2019 \mid 79
$$


Oleh karena itu diperlukan upaya untuk menyatukan kedua keilmuan itu agar tidak terjadi dikotomi antara keduanya. Upaya ini banyak dilakukan oleh beberapa tokoh. Salah satu tokoh yang berupaya untuk menggabungkan kedua keilmuan itu adalah Amin Abdullah. Ia adalah salah seorang intelektual Islam Indonesia. Penyatuan kedua keilmuan di atas dilakukan dengan mencetus sebuah gagasan yaitu integratif interkonektif yang diaplikasikan langsung di UIN Sunan Kalijaga. Integratif-interkonektif ini berusaha untuk menggabungkan antara keilmuan agama dengan ilmu sains serta filsafat. Upaya yang dilakukan oleh seorang tokoh pemikir sekaligus intelektual Islam ini berupa bangunan fisik maupun dalam hal keilmuan di UIN Sunan Kalijaga. Misalnya pengintegrasian antara Gedung keilmuan Islam dengan sains yang dahulunya tidak pernah dilakukan. Sedangkan dalam hal keilmuan yaitu memasukkan mata kuliah yang bersifat umum ke dalam studi keislaman begitupun sebaliknya agar tidak terjadi pemisahan atau dikotomi antara kedua ilmu tersebut.

Keywords: Ilmu agama dan Sains, Amin Abdullah, Integratifinterkonektif

\section{Pendahuluan}

Dalam sejarah Islam Klasik, pengembangan keilmuan hukumnya wajib bagi setiap orang Muslim apapun jenis ilmunya. Khazanah keilmuan ini tidak mengenal adanya pemisahan antara satu ilmu dengan ilmu lain seperti ilmu agama dan ilmu non-agama seperti yang terjadi saat sekarang ini. Semua ilmu adalah satu, berasal dari "Sumber Ilmu" yang satu dan harus digunakan manusia untuk lebih mengenal-Nya. ${ }^{1}$ oleh karena itu, antara ilmu agama dengan ilmu umum tidaklah bertentangan dan saling terikat antara satu dengan yang lain. Hubungan antara kedua keilmuan ini akan melahirkan kemajuan ilmu pengetahuan bagi manusia. Itu dapat dilihat dalam perkembangan modern saat ini.

Kemajuan sains dan pengetahuan dalam kehidupan manusia memerlukan arah dan pedoman. Agama adalah pedoman dan arah

${ }^{1}$ Pervez Hoodbhoy, Islam and Science, Religious Orthodoxy and the Battle for Rationality, terj. Sari Meutia, (Bandung: Mizan, 1996), h. 24

80 | TAJDID vol. 18, No. 1, Januari - Juni 2019 
kehidupan. Manusia tidak akan hidup dengan tenang apabila tidak dihiasi oleh nilai-nilai keagamaan. Agama sesungguhnya merupakan pembentuk akhlak manusia serta manusia juga tidak akan dapat hidup berkembang tanpa adanya sains. Oleh karena itu, antara ilmu agama dan sains sangatlah berhubungan dan saling melengkapi. Sains akan sempurna kalau manusia memiliki agama dan agama akan mendalam dan terang apabila diikuti oleh sains. ${ }^{2}$

Dalam perjalanan sejarah telah terjadinya dikotomi atau pemisahan antara ilmu keislaman dengan non keislamanan yang menyebabkan lemahnya pengembangan keilmuan di dunia Islam. Dikotomi ini berakibat fatal terhadap pengembangan keilmuan di negeri-negeri Muslim sehingga terjadi juga dikotomi dalam lembagalembaga Pendidikan. Seperti lembaga-lembaga pendidikan agama yang hanya mempelajari mata pelajaran agama dan tidak memasukkan ilmu-ilmu umum kedalamnya. Bahkan, ada juga yang menyebutkan jika mempelajari ilmu-ilmu umum yang berasal dari Barat akan membawa kepada kekafiran dan haram hukumnya. Akibatnya yaitu dunia Islam sekarang ini belum mampu bersaing dengan dunia luar yang telah mampu dan canggih baik dari bidang teknologi dan ilmu pengetahuannya. Selain itu, keilmuan umum yang tidak berdasarkan nilai-nilai keagamaan akan bebas nilai dan tidak memperdulikan nilai-nilai moralitas dan kemanusiaan. Ini akan berdampak kepada kehidupan manusia seperti perang saudara dimana-mana, krisis makna hidup dan lain sebagainya. ${ }^{3}$ Dikotomi kedua ilmu ini sangat membekas di hati umat Muslim. Seperti halnya di atas, sebagian orang masih terkesan bahwa ilmu keislaman adalah satu hal dan ilmu non-keislaman adalah hal lain. Keadaan demikian sangatlah merugikan kaum muslim. Kerugian yang dirasakan oleh

${ }^{2}$ Hasan Basri Jumin, Sains dan Teknologi dalam Islam, Jakarta: PT RajaGrafindo Persada, 2012), cet. I, h. 2

${ }^{3}$ Roni Ismail dkk, Integrasi-Interkoneksi Keilmuan UIN Sunan Kalijaga: Sebuah Interpretasi dan Aplikasi, (Yogyakarta: Bagian Akademik UIN Sunan Kalijaga, 2013), h. 62 
umat muslim ialah mulai mundurnya keilmuan Islam. Penyebabnya yaitu mereka yang menganggap keilmuan non-keagamaan tidak penting, sedangkan antara keduanya tidak dapat dipisahkan.

Dengan melihat kondisi seperti di atas, muncullah beberapa tokoh yang berusaha untuk menyatukan kembali keilmuan Islam dengan umum. Di dunia Islam itu sendiri, tokoh yang telah berjasa seperti Naquib al-Attas ${ }^{4}$ yang sangat terkenal dalam penyatuan kembali dikotomi keilmuan ini. Selain itu, penyatuan ini juga dilakukan oleh seorang sastrawan Indonesia seperti Kuntowijoyo ${ }^{5}$. Di samping kedua tokoh yang telah disebutkan di atas, tidak kalah pentingnya sosok intelektual yang juga berpengaruh dalam penyatuan antara ilmu agama dan ilmu pengetahuan seperti $\mathrm{M}$. Amin Abdullah. Ia adalah seorang pemikir sekaligus intelektual Indonesia yang berusaha menyatukan dikotomi keilmuan Islam dengan ilmu umum. Gagasannya yang terkenal yaitu tentang integrasi-interkonektif keilmuan agama dan umum. Usaha ini langsung diaplikasikan di UIN Sunan Kalijaga sewaktu ia menjabat sebagi rektor di Perguruan Tinggi Islam itu. Integrasi-interkonetif

${ }^{4}$ Ia adalah seorang tokoh intelektual yang berasal dari Bogor, Jawa Barat. Lahir pada tanggal 5 September 1931. Usaha penyatuan antara ilmu agama dan sains al-Attas ini disebabkan karena melemahnya akhlak yang dimiliki oleh umat Islam dan tidak lagi seperti akhlak yang dicontohkan oleh Nabi SAW. Tujuan islamisasi oleh al-Attas ini bukan untuk melemahkan agama tatapi menunjukkan keistimewaan dari ajaran Islam yang tertuang dalam kitab suci al-Qur'an. Cara yang diberikan dalam islamisasi ilmu pengetahuan al-Attas yaitu dengan membersihkan unsur-unsur yang tidak mempunyai nilai-nilai islami dalam sebuah ilmu pengetahuan serta menghiasi nilai-nilai keislaman ke dalam ilmu pengetahuan agar menjadi nilai-nilai yang sempurna. Lihat Ilyas Hasan dan Dian R. Basuki, Ensiklopedi Oxford Dunia Islam Modern, (Bandung: Mizan, 2002), h. 157

${ }^{5}$ Ia adalah seorang sejarawan dan sastrawan Indonesia. Ia dilahirkan di Bantul, Yogyakarta pada 18 September 1943 dan meninggal pada 22 Februari 2005. Penyatuan antara ilmu-ilmu keislamanan dengan ilmu pengetahuan umum yaitu dengan konsep integralisasi yaitu pemaduan antara wahyu dan pengetahuan manusia dan secara objektifikasi yaitu produk ilmu harus benar-benar bersifat objektif. 
didasarkan atas paradigma agama dan sains atau paradigma penyatuan dan terpadu antara agama dan sains.

Paradigma ini mengandaikan terbukanya dialog di antara ilmuilmu. Peluang terjadinya dikotomi tertutup rapat. Tiga peradaban yang ada di dalamnya yaitu budaya teks (Hadarah al-Nas), budaya ilmu (hadarah al-ilm) dan yang terakhir budaya filsafat (hadarah alfalsafah). Gagasan ini bertujuan untuk memecahkan kebuntuan dari problematika kekinian sehingga terhindar dari sifat arogansi keilmuan (single entity), terjadi isolasi berbagai bidang ilmu atau tidak adanya saling tegur (isolated entities). ${ }^{6}$ Penyatuan ini dilakukan dengan memposisikan dan menghubungkan antara agama dan sains secara tegas dan jelas. Berkaitan dengan hal tersebut, maka penulis tertarik untuk mengkaji lebih dalam lagi terkait dengan epistemologi keilmuan integrasi-interkonetif M. Amin Abdullah dan implikasinya dalam khazanah keilmuan Islam.

Berangkat dari latar belakang masalah yang telah di paparkan sebelumnya, maka artikel ini hendak mengetahui bagaimana Epistemologi Keilmuan Integrasi-Interkonektif M. Amin Abdullah, dan bagaimana implementasi keilmuan integrasi-interkonektif Amin Abdullah dalam bidang keislaman?

Dilihat dari tujuan yang ingin dicapai dari penelitian ini, setidaknya ada dua kegunaan umum yang bisa diharapkan. Pertama, secara teoritis, penelitian ini diharapkan dapat melengkapi bangunan epistemologi keilmuan integrasi interkonektif Amin Abdullah. Kedua, secara praktis penelitian ini diharapkan dapat dijadikan pijakan dalam melihat fenomena sosial tertentu secara filosofis terutama dalam masyarakat Islam, yang dapat dijadikan landasan untuk memiliki semangat juang dalam mencari karunia Allah SWT dan saling berbagi antar sesame sehingga melahirkan kemaslahatan

${ }^{6}$ Siswanto, Perspektif Amin Abdullah tentang Integrasi Interkoneksi Dalam Kajian Islam, jurnal Tasawuf dan Pemikiran Islam, vol. 3. No. 2. Tahun 2013. h. 379

TAJDID vol. 18, No. 1, Januari - Juni $2019 \mid 83$ 
sosial. Selain itu, adanya semangat dalam mengkaji bukan hanya keilmuan Islam namun juga keilmuan umum begitu pun sebaliknya.

Jenis penelitian dalam artikel ini adalah library Research atau studi kepustakaan. Artinya, penelitian ini dilakukan melalui penelusuran dan telaah terhadap karya-karya ilmiah baik yang tertuang dalam buku, majalah, jurnal, makalah, serta berbagai media yang mengulas topik penelitian. Sumber data dalam penelitian ini meliputi dua hal, yaitu sumber primer dan sumber sekunder. Adapun sumber data primer yaitu sumber data yang langsung dikumpulkan peneliti dari sumber pertamanya. Dalam hal ini buku-buku karangan Amin Abdullah. Adapun sumber sekunder yaitu karya-karya lain yang membahas tentang Amin Abdullah terkait dengan epistemologi keilmuan integrasi interkonektif serta karya-karya lainnya.

Untuk mempermudah penelitian ini, peneliti menggunakan beberapa metode yaitu metode pengumpulan data dan metode analisis data. Metode pengumpulan data merupakan langkah yang sangat penting dalam melakukan penelitian. Tanpa upaya pengumpulan data berarti penelitian tidak dapat dilakukan. ${ }^{7}$ Langkah awal yang dilakukan penulis dalam penelitian ini adalah mengelompokkan data-data yang berhubungan dengan masalah penelitian yaitu buku-buku terkait dengan integrasi interkonektif Amin Abdullah. Sedangkan metode analisis data digunakan untuk memahami dan menginterpretasikan pernyataan-pernyataan yang berhubungan dengan subjek penelitian ini sehingga diperoleh kejelasan arti atau makna yang terkandung di dalam pernyataan itu. Metode yang digunakan dalam penelitian ini adalah metode interpretasi. Metode ini untuk menginterpretasikan karya-karya Amin Abdullah untuk mengungkap gagasan ataupun ide-idenya.

${ }^{7}$ Mahi M. Hikmat, Metode Penelitian: Dalam Perspektif Ilmu Komunikasi dan Sastra, (Yogyakarta: Graha Ilmu, 2011), h. 71 


\section{Biografi M. Amin Abdullah}

Muhammad Amin Abdullah atau sering disingkat dengan nama M. Amin Abdullah dilahirkan di Margomulyo, Tayu, Pati, Jawa Tengah pada tanggal 28 Juli 1953 dari pasangan seorang santri didikan pondok pesantren $\mathrm{H}$. Ahmad Abdullah dan seorang priyayi Siti 'Aisyah yang berasal dari Madiun, Jawa Timur. M. Amin Abdullah ialah anak pertama dari delapan bersaudara yang masingmasingnya bernama Muhammad Makmun, Muhammad Anas, Siti Hindun, Muhammad Lukman, Siti Asma', Siti Alfiyah dan yang terakhir Siti Rasyidah. ${ }^{8}$

Amin Abdullah hidup di sebuah desa kecil yang mayoritas penduduknya bermata pencaharian sebagai petani dan peternak. Sebelum melanjutkan pendidikannya ke Gontor, Amin Abdullah menempuh Pendidikan di Sekolah Dasar (SD) Margomulyo sekitaran tahun 1960-1966. Di samping itu, ia juga mengikuti MWB atau Madrasah Wajib Belajar (seperti Madrasah Diniyah Sore Hari) yang berada tidak jauh dari rumahnya. Malam harinya menjelang Shalat Isya', Amin Abdullah belajar membaca Al-Qur'an bersama bapaknya Ahmad Abdullah dan dari beliaulah Amin untuk pertama kalinya belajar agama Islam. ${ }^{\text {? }}$

Setelah menamatkan pendidikannya di Sekolah Dasar Margomulyo, Amin Abdullah melanjutkan pendidikannya di Gontor yang diantar langsung oleh ibunya, 'Aisyah dan Bulek Tatik (adik ibunya). Enam tahun kemudian, ia menamatkan Pendidikan Menengah di Kuliyyat al-Mu'allimin al-Islamiyyah (KMI) setingkat SMP Pesantren Gontor, Ponorogo. Selama belajar di KMI, ia tergolong sebagai siswa yang tekun dan aktif baik dalam hal akademis maupun non akademis. Ini terlihat dalam keikutsertaan Amin pada kegiatan

${ }^{8}$ Waryani Fajar Riyanto, Integrasi-Interkoneksi Keilmuan: Biografi Intelektual M. Amin Abdullah (1953-...), (Yogyakarta: SUKA Press, 2013), h. 158

${ }^{9}$ Waryani Fajar Riyanto, Integrasi-Interkoneksi Keilmuan: Biografi Intelektual M. Amin Abdullah (1953-...), h. 163

$$
\text { TAJDID Vol. 18, No. 1, Januari - Juni } 2019 \mid 85
$$


pramuka dan juga menulis. Pada tahun 1977, Amin Abdullah kemudian melanjutkan pendidikannya pada Program Sarjana Muda (Bakalaureat- B.A.) di Institut Pendidikan Darussalam (IPD) Gontor. Setelah menamatkan Pendidikan di sana ia kemudian melanjutkan kuliah ke IAIN Sunan Kalijaga Yogyakarta dengan jurusan Perbandingan Agama (PA) dan lulus pada tanggal 3 Desember 1981 dengan judul skripsi: "Konsep Hak Kebebasan Beragama menurut Kristen dan Islam". ${ }^{10}$

Selama Amin Abdullah menempuh Pendidikan di IAIN Sunan Kalijaga, ia juga mengajar di Pabelan ${ }^{11}$ dan tentunya menjadi tempat yang sangat istimewa bagi Amin karena disinilah ia menemukan cinta sejatinya yang sekaligus murid Amin di Pabelan. Selain itu, Amin Abdullah juga pernah menjadi asisten dari Mukti Ali untuk mengampu mata kuliah Perbandingan Agama. Dapat diketahui juga bahwa Amin merupakan salah satu murid yang paling dekat dengan Mukti Ali karena di antara ratusan mahasiswa Mukti Ali hanya Amin Abdullah yang lulus ujian tanpa adanya remedial atau pengulangan.

Setelah Amin menamatkan kuliahnya di IAIN Sunan Kalijaga, ia menikah dengan salah seorang muridnya ketika mengajar di Pabelan, Nurkhayati. Pernikahan mereka dilaksanakan pada tanggal 8 Januari 1982. ${ }^{12}$ Pada tahun 1985, atas sponsor dari Departemen Agama Republik Indonesia dan Pemerintahan Turki Amin melanjutkan program Ph. D bidang studi Filsafat pada Department

${ }^{10}$ Amin Abdullah, Islamic Studies di Perguruan Tinggi Pendekatan Integratif-Interkonektif, (Yogyakarta: Pustaka Pelajar, 2006), h. 431

11 Pebelan merupakan sebuah pondok pesantren yang terletak di Mungkid, Magelang, Jawa Tengah yang mempunyai keterkaitan tersendiri dengan alumnialumni Gontor. Ini dikarenakan salah seorang penerus Pondok ini merupakan alumni Gontor dan salah satu santri kinasihnya Kyai Imam Zarkasyi (Pendiri Pondok Modern Gontor). Oleh karenanya tidak mengherankan jika Amin selaku alumni Gontor bisa mengajar di Pabelan. Dan menurut salah satu sumber, Amin Abdullah disebutkan secara eksplisit sebagai salah satu ustadz yang membuat pesantren ini maju dan alumninya menonjol di masyarakat.

12Waryani Fajar Riyanto, Integrasi-Interkoneksi Keilmuan: Biografi Intelektual M. Amin Abdullah (1953-...), h. 177

86 | TAJDID vol. 18, No. 1, Januari - Juni 2019 
of Philosophy, Faculty of Art and Science, Middle East Technical University (METU), Ankara, Turki. Keberangkatan ini membutuhkan pertimbangan yang cukup sulit karena saat itu ia telah menikah dengan Nurkhayati dan memiliki seorang anak perempuan yang baru berusia kurang lebih satu tahun. Selanjutnya pada tahun 1997-1998, Amin juga mengikuti program Post-Doctoral di McGill University, Kanada.

M. Amin Abdullah dikenal sebagai sosok yang aktif di berbagai bidang. Ia pernah menjabat sebagai Ketua Divisi Ummat, Orwil Daerah Istimewa Yogyakarta. Amin Abdullah pernah menjadi asisten Direktur Pascasarjana IAIN Sunan Kalijaga Yogyakarta (1993-1996), Wakil Kepala Lembaga Pengkajian dan Pengalaman Islam Universitas Muhammadiyah Yogyakarta (1992-1995), pembantu Rektor I, IAIN Sunan Kalijaga Yogyakarta (1998-2001), Guru Besar Ilmu Filsafat IAIN Sunan Kalijaga Yogyakarta (1999), dan tidak kalah pentingnya M. Amin Abdullah pernah menjabat sebagai rektor UIN Sunan Kalijaga selama dua periode yaitu dari tahun 2001-2010. Pada periode ini terjadinya transformasi dari IAIN menjadi UIN dan sebuah paradigma baru dalam lingkungan UIN Sunan Kalijaga yaitu Integrasi-Interkonektif yang menjadi cikal bakal keilmuan di UIN Sunan Kalijaga. Sosok M. Amin Abdullah digambarkan sebagai the right man in the right place, in the right momentum, and in the right intellectual. ${ }^{13}$

\section{Integrasi-Interkonektif Amin Abdullah}

Integrative itu sendiri berarti menyatu, menggabungkan. Sedangkan interkonektif dapat diartikan dengan menghubungkan. Dalam penggunaan integratif dalam Permendikbud No. 49 tahun 2014 tentang Standar Nasional Pendidikan Tinggi meniscayakan adanya unsur pendekatan antardisiplin dalam studi integrative

${ }^{13}$ Waryani Fajar Riyanto, Integrasi-Interkoneksi Keilmuan: Biografi Intelektual M. Amin Abdullah (1953-...), h. 395

$$
\text { TAJDID Vol. 18, No. 1, Januari - Juni } 2019 \mid 87
$$


meskipun tidak adanya penjelasan terkait hal tersebut. Ada beberapa istilah yang identik dengan integratif dan interkonektif. Pertama, tematik yaitu menyeluruh dalam satu tema. Kedua, holistic atau menyeluruh. Ketiga, pemaduan dan yang terakhir sinkron atau keserasian. $^{14}$

Sebelum memasuki pembahasan terkait dengan epistemologi keilmuan integrasi-interkonektif Amin Abdullah ini, terlebih dahulu kita harus mengetahui seluk beluk keilmuan tersebut. Integrasiinterkonektif ini digagas oleh Amin Abdullah ketika ia menjabat sebagai rektor UIN Sunan Kalijaga periode pertama. Pada periode ini ia mulai mentransformasi IAIN menjadi UIN Sunan Kalijaga. Syarat untuk menjadi sebuah UIN diperlukan perubahan yang mendasar di UIN, walaupun sebelumnya rektor-rektor sebelum Amin Abdullah telah berusaha untuk mengubah dan mengalihkan IAIN menjadi UIN namun itu semua terlaksana ketika Amin Abdullah menjabat sebagai rektor.

Paradigma integrasi interkonektif ini dibangun oleh Amin Abdullah sebagai respons atas persoalan masyarakat yang terjadi di era modern sekarang ini. Gagasan ini sebagai jawaban dari Amin Abdullah terkait dengan adanya dikotomi antara keilmuan Islam dengan keilmuan umum. Asumsi yang dibangun dalam paradigma ini adalah dalam memahami kompleksitas fenomena-fenomena yang terjadi di dalam kehidupan manusia baik dalam segi keilmuan apapun seperti ilmu agama, sosial, humaniora dan lain sebagainya tentu saja tidak dapat berdiri sendiri dan saling terkait dan membutuhkan. Menurut Badarussyamsi, adanya keterkaitan serta saling menyatunya antara satu ilmu dengan ilmu lainnya seperti ilmu agama dan ilmu sains serta ilmu-ilmu yang ada dapat membantu dalam memecahkan permasalahan yang ada dalam kehidupan

${ }^{14}$ Amin Abdullah, Implementasi Pendekatan Integratif-Interkonektif dalam Kajian Pendidikan Islam, (Yogyakarta: Pascasarjana UIN Sunan Kalijaga Yogyakarta, 2014), h. 33 
manusia. $^{15}$

Jadi dapat dikatakan bahwasannya paradigma ini membuka pandangan baru bagi manusia beragama dan ilmuwan agar lebih terbuka dan tidak saling menyalahkan antara satu ilmu dengan ilmu lain serta antara disiplin ilmu semakin mencair meskipun masih ditemukan batas-batas atau blok dalam keilmuan.

Paradigma integrasi-interkonektif menurut Amin Abdullah pada hakikatnya ingin menunjukkan bahwa antar berbagai bidang keilmuan, termasuk antar pendekatan yang dipakai dalam kajian sebenarnya saling memiliki keterkaitan karena memang yang dibidik oleh seluruh disiplin ilmu adalah realitas dan alam semesta yang sama hanya saja dimensi dan fokus perhatian yang dilihat oleh masing-masing disiplin ilmu berbeda. Oleh karena itu usaha untuk pemilahan secara dikotomis antara bidang-bidang keilmuan hanya akan merugikan diri sendiri. oleh karena itu mengkaji suatu bidang keilmuan dengan memanfaatkan bidang keilmuan yang lainnya itulah integrasi dan melihat ketersalingkaitan antara berbagai disiplin ilmu itulah interkoneksi. ${ }^{16}$

Adapun tawaran dari keilmuan integratif-interkonektif adalah:

\section{Memulai dari gagasan normativitas dan historisitas Islam.}

Agama sebagai produsen budaya dan produk budaya, pentingnya membedakan antara agama dan pemikiran keagamaan. Paradigma integratif-interkonektif dalam pengembangan studi Islam. Beberapa kegelisahan akademis yang memasung pemikiran Islam antara lain. Pertama, Truth Claim dan dogmatism pemikiran Islam. Kedua, adanya dikhotomi antara keilmuan Islam dengan umum. Ketiga, tantangan globalisasi. Dan terakbir, kurangnya

15 Badarussyamsi, B. (2015). Spiritualitas Sains Dalam Islam: Mengungkap Teologi Saintifik Islam. MIQOT: Jurnal Ilmu-Imu Keislaman, 39(2).

${ }^{16}$ Roni Ismail dkk, Integrasi-Interkoneksi Keilmuan UIN Sunan Kalijaga: Sebuah Interpretasi dan Aplikasi, h. 40

$$
\text { TAJDID Vol. 18, No. 1, Januari - Juni } 2019 \mid 89
$$


pendekatan historis, empiris, kritikal-anatikal dalam memahami fenomena sosial keagamaan. Amin Abdullah sebelum mengusung keilmuan integratf-interkonektif terlebih dahulu menggagas tentang normativitas dan historisitas yang terdapat dalam sebuah karyanya yang berjudul Studi Agama: normativitas atau historisitas. Dari sinilah cikal bakal munculnya epistemology keilmuan integratifinterkonektif.

\section{Studi Agama: Normativitas-Historisitas}

Sebelum Amin merumuskan model integrasi-interkonektif, ia pertama kali merumuskan model diadik dengan normativitas dan historisitas. Menurut Amin hubungan antara dimensi normativitas dan historisitas itu seperti manusia itu sendiri. Keberadaan manusia itu terdiri dari sisi normativitas dan historisitas. Hubungan keduanya ini diibaratkan dengan sebuah koin (mata uang) dengan dua permukaan. $^{17}$

Agama tidak bisa lepas dari dua dimensi yaitu historis dan normatif. Pada dimensi normatif, kita mengakui adanya realitas transendental yang bersifat mutlak dan universal, melampaui ruang dan waktu. Inilah realitas ketuhanan (Tuhan yang hakiki). Sedangkan dimensi historis, agama tidak bisa dipisahkan dengan sejarah dan kehidupan umat manusia yang berada dalam ruang dan waktu. Oleh karenanya, akses pemahaman manusia terhadap realitas transendental agama tidak akan pernah sama persis seperti apa yang

${ }^{17}$ Hubungan antara keduanya tidak harus mengambil posisi berhadaphadapan dan bersifat dikotomis. Hubungan keduanya adalah ibarat sebuah koin (mata uang) dengan dua permukaan. Hubungan antara kedua permukaan koin tidak dapat dipisahkan tetapi secara tegas dan jelas dapat dibedakan. Hubungan antara keduanya bukan seperti dua entitas yang berdiri sendiri-sendiri dan saling berhadap-hadapan tetapi keduanya teranyam, terjalin dan terajut sedemikian rupa, sehingga keduanya menyatu dalam satu keutuhan yang kokoh dan kompak" lihat M. Amin Abdullah, studi agama: normativitas atau historisitas, (Yogyakarta: pelajar 2002), h. v

90 | TAJDID vol. 18, No. 1, Januari - Juni 2019 
dikehendaki-Nya. Ia hanyalah batas dari manifestasi keberagamaan umat manusia dalam menghayati spiritualitas agama. ${ }^{18}$

Aspek normativitas adalah ajaran wahyu yang bersifat doktrinal-teologis dan aspek keagamaan adalah telaah dari sudut pendekatan keilmuan sosial-keagamaan yang bersifat multi dan interdisipliner baik lewat pendekatan historis, filosofis, psikologis, sosiologis, kultural maupun antropologis. ${ }^{19}$ Kedua pendekatan ini bagi Amin Abdullah merupakan hubungan yang seharusnya tidak dapat dipisahkan satu sama lain. Kedua pendekatan ini sangat diperlukan dalam melihat keberagamaan masyarakat pluralistik. Keduanya akan saling mengoreksi, menegur dan memperbaiki kekurangan yang ada pada kedua pendekatan ini. Pendekatan teologis-normatif saja akan menghantarkan masyarakat kepada keterkungkungan berfikir sehingga akan muncul truth claim sehingga melalui pendekatan historis-empiris akan terlihat seberapa jauh aspek-aspek eksternal seperti aspek sosial, politik, ekonomi yang ikut bercampur dalam praktek-praktek ajaran teologis. ${ }^{20}$

Amin Abdullah berusaha untuk merumuskan kembali penafsiran ulang agar sesuai dengan tujuan dari jiwa agama itu sendiri, di sisi lain gagasan itu dituntut mampu menjawab tuntunan zaman, di mana membutuhkan kebebasan dalam berpikir, berkreasi dan berinovasi yang terus menerus serta menghindari keterkungkungan berpikir. Keterkungkungan berpikir disebabkan adanya penilaian terhadap suatu hal bersikap objektif, tidak terbukanya terhadap kebenaran lain serta tidak menerima kebenaran yang datang dari luar. Pemikiran seperti inilah yangh harus dihindari oleh manusia pada umumnya. Manusia dituntut untuk terbuka dan menerima semua kebenaran yang datang dari luar asalkan mampu

${ }^{18}$ Waryani Fajar Riyanto, Integrasi-Interkoneksi Keilmuan: Biografi Intelektual M. Amin Abdullah (1953-...), h. 994

${ }^{19}$ Amin Abdullah, Falsafah Kalam di Era Postmodernisme, (Yogyakarta: Pustaka Pelajar, 1995), h. 21

${ }^{20} \mathrm{M}$. Amin Abdullah, studi agama: normativitas atau historisitas, h. 5

$$
\text { TAJDID Vol. 18, No. 1, Januari - Juni } 2019 \mid 91
$$


menyeleksi mana yang benar dan sesuai dengan ajaran Islam. Jangan sampai menerima begitu saja, diperlukan juga penyeleksian akan kebenaran yang datang dari luar. Oleh karena itulah diperlukan pemikiran yang matang. 2

\section{Paradigma Integrasi-interkonektif}

Dikotomi yang terjadi antara keilmuan umum dengan keilmuan agama merupakan suatu hal yang memprihatinkan. Keadaan ini sangat berpengaruh terhadap pendidikan serta ilmu pengetahuan yang ada di Tanah Air. Adanya perguruan tinggi yang hanya mengajarkan terkait dengan keilmuan umum seperti perguruan tinggi umum dan ada pula yang hanya keilmuan agama seperti perguruan tinggi agama. Padahal seperti yang diketahui, antara kedua keilmuan itu saling keterkaitan dan saling berhubungan. Lebih parahnya lagi, adanya anggapan bahwa jika mempelajari keilmuan umum apalagi yang berasal dari luar akan membawa kepada kesesatan dan dianggap kafir. Oleh karena itu, paradigma integrasi interkonektif yang ditawarkan oleh Amin Abdullah ini berusaha untuk memecahkan persoalan demikian. Paradigma ini berusaha untuk menyatukan antara natural sciences, sosial sciences dan humanities. Meskipun belum begitu terlihat penyatuan antara ketiga keilmuan ini, paling tidak telah terlihat bagaimana hubungan dan saling terkaitnya antara ketiganya ini.

Konsep integrasi-interkonektif ini memberikan pandangan bahwa semua ilmu pengetahuan yang telah berkembang dalam berbagai bidang itu sesungguhnya merupakan satu kesatuan yang saling berhubungan satu dengan lainnya. Misalkan apabila di sekolah dasar kita mengenai pembelajaran tematik dan pembelajaran integrasi-interkonektif ini hampir sama dengan pembelajaran tematik itu namun yang membedakannya adalah pembelajaran tematik hanya sekedar penjelasan bahwa setiap tema mengandung berbagai macam ilmu namun kalau integrasi-interkonektif lebih mengedepankan bahwa setiap ilmu itu tidak dapat dipisahkan nilai-

\section{2 | TAJDID vol. 18, No. 1, Januari - Juni 2019}


nilai khususnya nilai agama (Islam). Oleh karena itulah seorang ilmuan harus mengembangkan keilmuannya berasaskan kepada nilai nilai agama. Begitupun sebaliknya, ilmu agama yang syarat akan nilai tidak bisa dipisahkan dengan ilmu pengetahuan ketika agama berhadapan dengan perkembangan peradaban manusia yang semakin hari semakin maju dan kompleks. ${ }^{21}$

Keilmuan interkonektif yang digagas Amin Abdullah menegaskan bahwa bangunan keilmuan apapun baik keilmuan agama, sosial, humaniora maupun kealaman tidak dapat berdiri sendiri to be single entity. Akan tetapi kerja sama, saling tegur sapa, saling membutuhkan, saling koreksi dan saling keterhubungan antara disiplin keilmuan akan lebih dapat membantu manusia dalam memahami kompleksitas persoalan kehidupan dan sekaligus upaya pemecahannya. Interkonektif ini memecahkan permasalahan tentang adanya dikotomi antara pendidikan umum dengan pendidikan agama. ${ }^{22}$

Pendekatan integrasi-interkonektif merupakan pendekatan yang tidak akan saling melumatkan dan peleburan antara keilmuan umum dan agama. Pendekatan keilmuan umum dan agama Islam dapat dibagi menjadi tiga corak yaitu paralel, linear dan sirkular. ${ }^{23}$ Pendekatan integrasi-interkoneksi adalah pendekatan yang berusaha saling menghargai, keilmuan umum dan agama sadar akan

${ }^{21}$ Waryani Fajar Riyanto, Integrasi-Interkoneksi Keilmuan: Biografi Intelektual M. Amin Abdullah (1953-...), h. 1024

${ }^{22}$ Roni Ismail dkk, Integrasi-Interkoneksi Keilmuan UIN Sunan Kalijaga: Sebuah Interpretasi dan Aplikasi, h. 66

${ }^{23}$ Corak paralel merupakan corak di mana masing-masing ilmu akan berjalan sendiri-sendiri tanpa ada hubungan dan persentuhan antara satu dengan lainnya. Selain itu corak linear adalah di mana salah satu dari keduanya akan menjadi primadona sehingga ada kemungkinan berat sebelah. Sedangkan corak sirkular merupakan corak di mana masing-masing ilmu dapat memahami keterbatasan, kekurangan dan kelemahan yang melekat pada diri masing-masing dan sekaligus bersedia mengambil manfaat dari temuan-temuan yang ditawarkan oleh tradisi keilmuan lain serta memiliki kemampuan untuk memperbaiki kekurangan yang melekat pada diri sendiri.

$$
\text { TAJDID vol. 18, No. 1, Januari - Juni } 2019 \mid 93
$$


keterbatasan masing-masing dalam memecahkan persoalan manusia dan akan melahirkan sebuah kerja sama setidaknya saling memahami pendekatan dan metode berpikir di antara kedua ilmu itu. ${ }^{24}$

Perbedaan mendasar antara islamisasi ilmu dengan integrasi adalah dalam hal pelumatan keilmuan umum dan agama. Dalam islamisasi ilmu, keilmuan Islam akan memilih dan memilah ilmuilmu yang dianggap Islami dan ilmu yang bukan Islami dengan menghilangkan ilmu-ilmu yang bukan Islami atau yang tidak cocok dengan nilai-nilai keislamanan. Sedangkan integrasi dalam hal ini berkaitan dengan usaha memadukan keilmuan umum dengan Islam tanpa harus menghilangkan keunikan-keunikan antara kedua keilmuan ini. ${ }^{25}$

Konsep integrasi-interkonektif Amin Abdullah merupakan jalan tengah antara konsep islamisasi ilmu ${ }^{26}$ oleh Ismail Raji AlFaruqi dan ilmuisasi Islam oleh Kuntowijoyo. Amin Abdullah tidak menolak kedua pandangan dari tokoh tersebut terkait dengan Islamisasi Ilmu dan Ilmuisasi Islam, namun disini Amin juga berdialog terkait dengan isu seputar Islamisasi Ilmu. Di sisi lain ia juga mengambil sebagian teori dari Ilmuisasi Islam. Namun, pada akhirnya Amin merumuskan sendiri paradigmanya yang disebut dengan integrasi-interkonektif. Dengan demikian, yang menjadi persoalan menurut Amin Abdullah adalah bagaimana setiap ilmu yang dikembangkan itu harus dalam kerangka tiga perspektif yaitu

\footnotetext{
${ }^{24}$ Amin Abdullah, Islamic Studies: Paradigma Integrasi-Interkoneksi Sebuah Antologi, (Yogyakarta: SUKA Press, 2007), h. 53

${ }^{25} \mathrm{Amin}$ Abdullah, Islamic Studies: Paradigma Integrasi-Interkoneksi Sebuah Antologi, h. 50

${ }^{26}$ Islamisasi ilmu Ismail Raji ini adalah bagaimana upaya untuk menarik ilmuilmu pengetahuan (konteks) yang dianggap kurang islami ke ranah teks Islam. Islamisasi ilmu pada dasarnya adalah suatu upaya pembebasan pengetahuan dari asumsi-asumsi Barat dan kemudian menggantikannya dengan pandangan keislaman. Menurut pandangan Hamdi, islamisasi Ilmu ini selalu mengambil semangat kembali kepada al-Qur'an dan Hadis dengan meletakkannya sebagai sumber ilmu pengetahuan.
}

\section{4 | TAJDID vol. 18, No. 1, Januari - Juni 2019}


perspektif teks (hadarat an-nas), perspektif ilmu pengetahuan (badarat al-ilm) dan perspektif filosofis yang kritis dan transformatif (hadarat al-falsafah).

Hadarat al-Tlm merupakan ilmu-ilmu empiris seperti sains, teknologi, dan ilmu-ilmu yang terkait dengan realitas tidak lagi berdiri sendiri tetapi juga bersentuhan dengan hadarat al-Falsafah sehingga tetap memperhatikan etika emansipatoris. Begitu juga sebaliknya, hadarat al-falsafah akan terasa kering dan gersang apabila tidak dikaitkan dengan isu-isu keagamaan yang termuat dalam budaya teks dan lebih-lebih jika menjauh dari problem-problem yang ditimbulkan dan dihadapi oleh hadarat al-ilm. Dari hadarah tersebut melahirkan pola single entity, isolated entities, dan interconnected. ${ }^{27}$

Dalam konteks trikotomik hadarat ini, Islamisasi Ilmu lebih cenderung kepada wilayah hadarat an-nas dan Ilmuisasi Islam lebih cenderung kepada hadarat al-ílm. Sebagaimana dalam bagan di bawah ini: ${ }^{28}$

Islamisasi Ilmu

Konteks (ilmu)

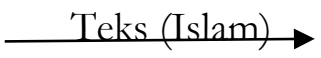

Ilmuisasi Islam

Teks (Islam)

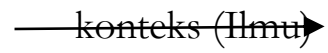

Integrasi-Interkonektif

hadarat an-nas

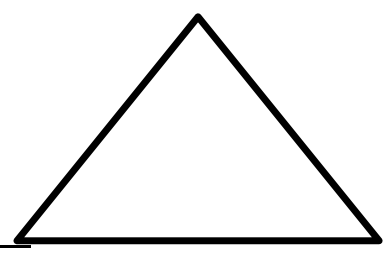

${ }^{27}$ Amin Abdullah, Islamic Studies di Perguruan Tinggi Pendekatan Integratif-Interkonektif, h. 402-403

${ }^{28}$ Waryani Fajar Riyanto, Integrasi-Interkoneksi Keilmuan: Biografi Intelektual M. Amin Abdullah (1953-...), h. 772

$$
\text { TAJDID vol. 18, No. 1, Januari - Juni } 2019 \mid 95
$$



' $\mathrm{Ilm}$

Secara epistemologis, interkonesitas merupakan jawaban atas respon terhadap kesulitan-kesulitan yang dirasakan selama ini, yang diwariskan dan diteruskan selama berabad-abad dalam peradaban Islam tentang adanya dikotomi pendidikan umum dan pendidikan agama. Masing-masing berdiri sendiri tanpa adanya saling sapa. Namun secara aksiologis, paradigma interkoneksitas hendak menawarkan pandangan dunia manusia beragama dan ilmuan yang baru yang lebih terbuka mampu membuka dialog dan kerja sama, transparan, dapat dipertanggungjawabkan secara publik dan berpandangan ke depan. Sedangkan secara ontologis, hubungan antara berbagai disiplin ilmu menjadi semakin terbuka dan cair, meskipun blok-blok dan batas-batas wilayah antara kedua budaya pendukung keilmuan agama yang bersumber pada teks-teks (badarat an-nas), dan budaya pendukung keilmuan faktual-historis empiris, yakni ilmuilmu sosial dan ilmu-ilmu kealaman (hadarat al-ilm) serta budaya pendukung keilmuan etis-filosofis (hadarat al-falsafah) masih tetap saja ada hanya saja cara berpikir dan sikap ilmuan yang membidangi dan menekuni ilmu-ilmu ini yang harus dirubah. ${ }^{29}$

Konsep keilmuan integrasi-interkonektif dengan trikotomik badarat-nya adalah konsep keilmuan yang terpadu dan terkait antara keilmuan agama (an-nas), dengan keilmuan alam dan sosial (ilm) dengan harapan menghasilkan sebuah out put yang seimbang dengan etis filosofis (al-falsafah). Jadi, hubungan antara bidang keilmuan tidak lagi terjadi konflik dan tetapi saling menghargai dan membangun, bidang keilmuan satu sama lain saling mendukung. Misalkan bagaimanan keilmuan sains dan teknologi dapat mendukung eksistensi keilmuan agama, begitu juga sebaliknya.

${ }^{29}$ Waryani Fajar Riyanto, Integrasi-Interkoneksi Keilmuan: Biografi Intelektual M. Amin Abdullah (1953-...), h. 776

96 | TAJDID vol. 18, No. 1, Januari - Juni 2019 
Adanya hubungan yang erat antara keilmuan agama, keilmuan alam dan sosial serta filsafat seperti yang terdapat dalam gambar di bawah ini: $:^{30}$

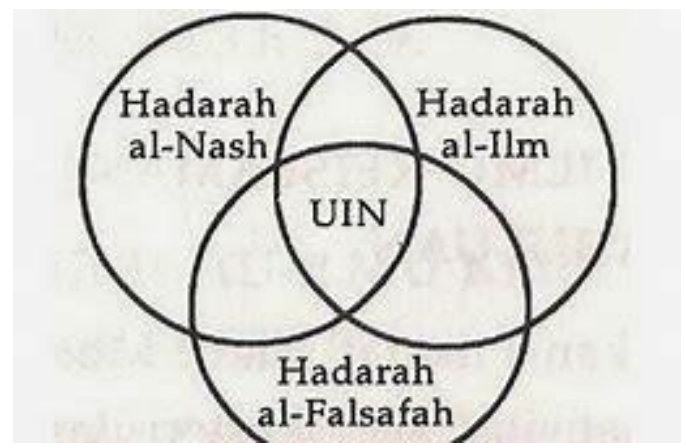

Pada skema di atas dapat diketahui bahwa masing-masing rumpun ilmu sadar akan keterbatasan-keterbatasan yang melekat dalam diri sendiri dan bersedia untuk berdialog, bekerja sama dan memanfaatkan metode dan pendekatan yang digunakan oleh rumpun ilmu lain untuk melengkapi kekurangan yang melekat jika keilmuan itu terpisah satu dengan yang lain. Diperlukan upaya yang sungguh-sungguh dari berbagai pihak dari waktu ke waktu dengan kesediaan mengorbankan kepentingan pribadi demi menyongsong realisasi keilmuan baru pada era UIN. Begitu jelaslah bagaimana keterkaitan antara satu ilmu dengan ilmu lainnya baik bidang keagamaan maupun bidang umum sehingga tidak akan terjadi lagi dikotomi antara keilmuan itu. ${ }^{31}$

Paradigma integrasi interkonektif Amin Abdullah sangat dipengaruhi oleh Muhammad Abid al-Jabiri. Ia membagi epistemologi Islam kepada tiga aspek yaitu epistemologi burbani, epistemologi irfani dan epistemologi bayani. Muhammad abid alJabiri memandang bahwa epistemologi irfani tidak penting dalam

${ }^{30} \mathrm{Amin}$ Abdullah, Islamic Studies: Paradigma Integrasi-Interkoneksi Sebuah Antologi, h. 38

${ }^{31}$ Amin Abdullah, Islamic Studies: Paradigma Integrasi-Interkoneksi Sebuah Antologi, h. 38

TAJDID vol. 18, No. 1, Januari - Juni $2019 \mid 97$ 
perkembangan pemikiran Islam sedangkan menurut Amin Abdullah antara ketiganya sangat penting dan saling beriringan. Bunganan yang baik antara ketiga ini tidak dalam bentuk paralel ataupun linear melainkan dalam bentuk sirkular. Bentuk dari paralel akan melahirkan corak epistemologi yang berjalan sendiri-sendiri tanpa adanya hubungan dengan yang lain serta tidak adanya keterkaitan. Bentuk linear akan melahirkan asumsi bahwa salah satu dari ketiganya akan menjadi primadona sehingga sangat tergantung pada latar belakang, kecendrungan kepentingan pribadi atau kelompok. Sedangakan yang terakhir yaitu bentuk sirkular diharapkan masingmasing corak epistemologi keilmuan dalam Islam akan memahami kekurangan dan kelebihan masing-masing sehingga dapat mengambil manfaat dari temuan-temuan yang ditawarkan oleh tradisi keilmuan lain dalam rangka memperbaiki kekurangan yang ada. ${ }^{32}$

Konsep integrasi-interkoneksi dari Amin Abdullah dapat dilihat dalam jaring laba-laba atau spider web kreasi dari Amin Abdullah:

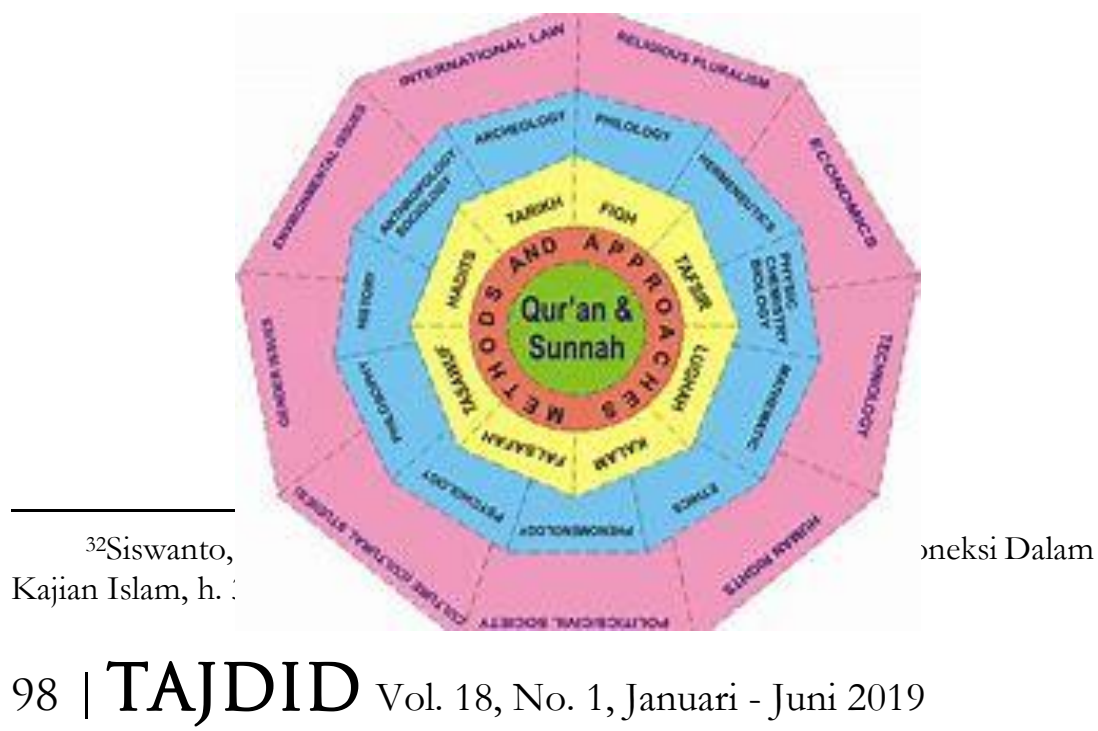


Dalam jaring laba-laba di atas menjelaskan bahwa sumber dari segala ilmu itu adalah nash al-Qur'an atau Kalamullah dan alam semesta (hukum alam) Sunnatullah. Al-Qur'an dan alam semesta merupakan ciptaan Allah SWT dan juga disebut sebagai ayat-ayat Allah. Kalamullah disebut sebagai ayat-ayat qauliyab ${ }^{33}$ dan Sunnatullah disebut sebagai ayat Kamniyyah ${ }^{34}$. Oleh karena itu, tidak akan saling bertentangan. Jika ada pertentangan antara keduanya maka pasti ada salah satu pemahamannya yang salah. Semua ilmu pengetahuan yang ada dalam jaring laba-laba di atas digali dan dikembangkan dari dua sumber Kalamullah dan Sunnatullah tersebut dan Nampak jelas hubungan antara keilmuan itu. Garis putus-putus yang membatasi satu pengetahuan menunjukkan adanya pintu yang terbuka untuk saling menerima pengetahuan lainnya. ${ }^{35}$ oleh karena itu, sumber dari semua ilmu pengetahuan adalah al-Qur'an dan Sunnah. Jika terdapat pertentangan antara berbagai keilmuan yang ada maka diharapkan kembali kepada alQur'an dan Sunnah untuk memecahkan semua persoalan. Dapat juga dilihat bahwa semua keilmuan yang bersumber dari al-Qur'an dan Sunnah hendaknya harus saling berhubungan dan saling membantu dalam memecahkan permasalahan. Jangan sampai adanya dikotomi antara keilmuan itu.

${ }^{33}$ Ayat-ayat qauliyah adalah ayat-ayat yang difirmankan oleh Allah swt. di dalam Al-Qur'an. Ayat-ayat ini menyentuh berbagai aspek, termasuk tentang cara mengenal Allah.

${ }^{34}$ Ayat-ayat Kauniyah adalah ayat-ayat atau tanda yang wujud di sekeliling yang diciptakan oleh Allah. Ayat-ayat ini dalam bentuk benda, kejadian, peristiwa dan sebagainya yang ada di dalam alam ini.

${ }^{35}$ Sangkot dkk, Sosialisasi Pembelajaran UIN Sunan Kalijaga 2019, (Yogyakarta: Bagian Akademik UIN Sunan Kalijaga, 2019), h. 62

$$
\text { TAJDID vol. 18, No. 1, Januari - Juni } 2019 \mid 99
$$


Hubungan antara integrasi-interkonektif, triple hadarat dan model spider web yang digagas oleh Amin Abdullah adalah seperti model pancara energi dalam istilah ilmu fisika. Dimana sumber energinya (matahari) adalah integrasi-interkoneksi, pancarannya (spektrum sinar-sinar) adalah trikotomik hadarat, dan hasil pancarannya adalah spider web atau jaring laba-laba (warna-warni pelangi).

Salah satu implementasi keilmuan integrasi-interkonektif Amin Abdullah dalam betuk wujud bangunan fisik diantaranya terkait dengan arsitek bangunan. Pertama, semua bangunan Gedung di UIN harus terintegrasi dan terinterkoneksi antara satu dengan yang lain. Hal ini diwejawantahkan dengan adanya bangunan jembatanjembatan koneksitas yang menghubungkan antara gedung termasuk jembatan koneksitas yang melintas di atas jalan Timoho yang menghubungkan antara Mazhab Timur (religion) dan Mazhab Barat (Science). Hal ini diharapkan mampu menerobos dikotomi yang ada. Jika ada yang menilai bahwa antara keilmuan itu berbeda dan tidak terikat maka dengan adanya jembatan penghubung itu maka akan terlihat bagaimana antara keduanya saling terikat. Itu salah satu contoh dari pengaplikasian integrasi interkoneksi di lingkungan UIN Sunan Kalijaga. Kedua, bentuk arsitektur antara satu bangunan dengan bangunan lain harus plural, tidak monolitik. Ketiga, bangunan Gedung mengikuti desain akademik, yaitu mengutamakan fungsi daripada bentuk. Di sini dapat dilihat bagaimana implementasi dari keilmuan integrasi-interkonektif yang digagas oleh Amin Abdullah sewaktu ia menjabat menjadi rektor UIN Sunan Kalijaga. Harus adanya hubungan antara satu ilmu dengan ilmu lainnya.

\section{Implikasi bagi Pemikiran Islam}

Menurut hemat penulis, gagasan integrasi-interkonektif Amin Abdullah ini sangat berpengaruh dalam kemajuan pendidikan dan keilmuan di UIN Sunan Kalijaga. Integrasi-interkonektif ini memberikan gambaran yang baru dalam transformasi IAIN menjadi

$$
100 \text { | TAJDID vol. 18, No. 1, Januari - Juni } 2019
$$


UIN walaupun melalui tahap yang cukup sulit. Walaupun UIN yang notabene menggeluti bidang keislamanan namun tidak menutup kemungkinan juga mempelajari dan memasukkan kurikulum ilmuilmu umum ke dalam mata kuliahnya.

Paradigma yang ditawarkan oleh Amin Abdullah ini secara konseptual sangat relevan dengan perkembangan keilmuan Islam. Itu dapat dilihat dengan adanya dialog antar disiplin ilmu dan mengakibatkan semakin kuatnya keilmuan Islam dalam menghadapi tantangan zaman dengan segala perubahan yang ada. Seperti yang telah dijelaskan di atas, jika hanya menuntut kepada keilmuan agama saja tanpa mempelajari keilmuan umum maka akan berdampak kepada kemajuan keilmuan itu sendiri. kehidupan semakin hari semakin maju dan terus melahirkan penemuan-penemuan yang baru. Begitu juga dengan keilmuan umum. Jika hanya mengandalkan keilmuan umum tanpa disandarkan dengan keilmuan agama maka bisa saja ilmuan itu tidak memahami nilai-nilai agama dan hanya mengandalkan ilmu umum saja. Oleh sebab itu, antara keduan keilmuan baik agama dan umum saling berhubungan. Integrasi antara ilmu agama dan ilmu umum muncul di tengah kesadaran beragama yang sarat dengan kemajuan pengetahuan dan teknologi.

Konsep integrasi-interkonektif ini telah menyatukan dikotomi antara agama dan sains yang terjadi pada masyarakat sekarang ini. Adanya yang beranggapan bahwa kita hanya perlu mempelajari ilmuilmu keislamanan tanpa ilmu-ilmu umum. Namun, sebagaimana yang penulis ketahui, antara ilmu agama dan ilmu umum atau ilmu pengetahuan sangatlah berhubungan antara satu dengan yang lain. Antara kedua disiplin ilmu itu tidak dapat dipisahkan. Seorang ilmuan yang ingin mengembangkan keilmuannya harus berlandaskan kepada nilai-nilai agama atau dihiasi oleh nilai-nilai agama begitu pun sebaliknya. Oleh karena itu gagasan integrasiinterkonektif ini sangat penting dan cocok dalam pengembangan disiplin ilmu pada saat sekarang ini.

\section{TAJDID Vol. 18, No. 1, Januari - Juni $2019 \mid 101$}


Dalam dunia pendidikan, gagasan integrasi-interkonektif telah menghubungkan dan menyatukan antara bidang keilmuan umum dan agama. Mahasiswa tidak hanya terpaku terhadap ilmu-ilmu agama walaupun mereka notabene berasal dan belajar di perguruan tinggi Islam.

\section{Penutup}

Paradigma baru yang dibangun oleh Amin Abdullah dengan integratif-interkonektif ini memang sangat relevan dengan kebutuhan zaman saat ini. Koneksitas ini diharapkan mampu menjawab kebuntuan dalam keilmuan Islam dan lebih jauh lagi dapat menjawab kompleksitas problem kemanusiaan di era globalisasi. Namun paradigma ini tidak mudah untuk diaplikasikan, hal ini bisa dilihat ketika paradigma ini coba diterapkan dalam pengembangan perguruan tinggi agama yang mengejawantah dengan perubahan IAIN menjadi UIN ternyata banyak menimbulkan kerancuan terutama bagi program-program studi yang muncul kemudian.

Namun dalam hal ini, gagasan integrasi-interkonektif ini mampu menyatukan kembali bidang keilmuan agama dan umum dengan menggunakan pendekatan sirkular dan model trikotomi yaitu menggabungkan antara hadarat an-nas, hadarat al'ilm dan hadarat al-falsafah. Dengan penyatuan ini diharapkan tidak ada lagi dikotomi antara pendidikan agama dan pendidikan umum.

102 | TAJDID Vol. 18, No. 1, Januari - Juni 2019 


\section{Daftar Kepustakaan}

Abdullah, Amin. 1995. Falsafah Kalam di Era Postmodernisme. Yogyakarta: Pustaka Pelajar.

------, 2002. studi agama: normativitas atau historisitas. Yogyakarta: pelajar.

------, 2006. Islamic Studies di Perguruan Tinggi Pendekatan Integratif-Interkonektif. Yogyakarta: Pustaka Pelajar.

------, 2007. Islamic Studies: Paradigma Integrasi-Interkoneksi Sebuah Antologi. Yogyakarta: SUKA Press.

------, 2014. Implementasi Pendekatan Integratif-Interkonektif dalam Kajian Pendidikan Islam. Yogyakarta: Pascasarjana UIN Sunan Kalijaga Yogyakarta.

Badarussyamsi, B. (2015). Spiritualitas Sains Dalam Islam: Mengungkap Teologi Saintifik Islam. MIQOT: Jurnal IlmuIlmu Keislaman, 39(2).

Hasan, Ilyas dan Dian R. Basuki. 2002. Ensiklopedi Oxford Dunia Islam Modern. Bandung: Mizan.

Hikmat, Mahi M. 2011. Metode Penelitian: Dalam Perspektif Ilmu Komunikasi dan Sastra. Yogyakarta: Graha Ilmu.

Hoodbhoy, Pervez. 1996. Islam and Science, Religious Orthodoxy and the Battle for Rationality, terj. Sari Meutia. Bandung: Mizan.

Ismail, Roni, dkk. 2013. Integrasi-Interkoneksi Keilmuan UIN Sunan Kalijaga: Sebuah Interpretasi dan Aplikasi. Yogyakarta: Bagian Akademik UIN Sunan Kalijaga.

Jumin, Hasan Basri. 2012. Sains dan Teknologi dalam Islam. Jakarta: PT RajaGrafindo Persada.

Riyanto, Waryani Fajar. 2013. Integrasi-Interkoneksi Keilmuan: Biografi Intelektual M. Amin Abdullah (1953...). Yogyakarta: SUKA Press.

Sangkot dkk. 2019. Sosialisasi Pembelajaran UIN Sunan Kalijaga 2019. Yogyakarta: Bagian Akademik UIN Sunan Kalijaga.

$$
\text { TAJDID Vol. 18, No. 1, Januari - Juni } 2019 \text { | } 103
$$


Atika Yulanda

Siswanto, Perspektif Amin Abdullah tentang Integrasi Interkoneksi Dalam Kajian Islam, jurnal Tasawnf dan Pemikiran Islam, vol. 3. No. 2. Tahun 2013. h. 379

104 | TAJDID Vol. 18, No. 1, Januari - Juni 2019 